\title{
Comparative Studies on the Similarities and Diversities of the Legislations Regarding Earthquake Insurance in Asia-Examples of Japan, New Zealand and Taiwan
}

\author{
Wei-Chun Cheng \\ Long River Security Co., Taipei, Taiwan \\ Maginda Management and Maintenance Co., Taipei, Taiwan
}

\begin{abstract}
Earthquakes are one of the most threatening natural catastrophic risks for many Asian countries. The pecuniary losses from natural disasters, particularly earthquake, are much larger in advanced economies due to the accumulation and concentration of valuable capital, and the potential losses are much higher than in low income countries. As one of the most commonly utilized risk financing mechanism, the insurance industry is playing a critical role in post-disaster financing of the countries affected. Surprisingly, earthquake insurance penetration, in fact, is still quite low, even in some industrialized countries with high seismic risk. This is because the low-probability/high-consequence nature of catastrophic risk, like earthquake damages, poses difficult challenges for property owners, insurers, and reinsurers. This paper argues that, with some sort of government intervention, catastrophic risk results from an earthquake can be insurable and affordable. This paper will also analyze obstacles facing the successful creation of a compulsory earthquake insurance system while advocating its essentiality.
\end{abstract}

Keywords: insurance, earthquake insurance, catastrophic risk, catastrophe, catastrophic insurance, disaster relief

\section{Introduction}

Earthquakes are one of the most threatening natural catastrophic risks for many Asian countries. On March 11, 2011, an 8.9 magnitude earthquake struck Northern Japan, which incurred property losses of 50 billion US dollars and approximately 210 to 300 billion in total economic losses (5.4\% of the gross domestic product [GDP]) (Swiss Re, 2012a). A month earlier, Christchurch, New Zealand was hit by a 6.1 magnitude earthquake that caused property losses between three to five billion US dollars and 15 billion in total economic losses (10\% of the GDP) (Swiss Re, 2012a). Taiwan, an island situated at the junction of the Eurasia Plate and Philippine Sea Plate, is also on a high-risk seismic belt, where damage associated with an earthquake is likely to be as tremendous as that in Japan or New Zealand. In fact, Taiwan's 921 Earthquake, also known as the Jiji Earthquake, was of 7.3 magnitude. It occurred on September 21, 1999, and caused the death of 2,415 people and approximately US\$10 to 12 billion in economic losses (Dong et al., 2000). The pecuniary losses from natural disasters are much larger

Wei-Chun Cheng, LL.B. (Taiwanese equivalent to J.D., National Taipei University, Taipei, Taiwan); LL.M. candidate (Taipei Medical University, Taipei, Taiwan), chairman, Long River Security Co., Taipei, Taiwan; Maginda Management and Maintenance Co., Taipei, Taiwan. 
in advanced economies due to the accumulation and concentration of valuable capital, and the potential losses are much higher than in low income countries (Laframboise \& Loko, 2012).

As one of the most commonly utilized risk financing mechanism, the insurance industry is playing a critical role in post-disaster financing of the countries affected. While insurance cannot replace lost lives and livelihoods, appropriate insurance and other risk transfer mechanisms can greatly accelerate the recovery process (Swiss Re, 2012b). Surprisingly, earthquake insurance penetration, in fact, is still quite low, even in some industrialized countries with high seismic risk. For example, the insurance industry indemnified no more than $17 \%$ for the disastrous event in Japan in March 2011 (Swiss Re, 2012b). This is because the low-probability high-consequence nature of catastrophic risk, like earthquake damages, poses difficult challenges for property owners, insurers, and reinsurers. First, the high transaction costs affect the insurability of catastrophic risks (Gollier, 2005). Second, particularly in the case of a catastrophic earthquake, the insufficient international diversification of risk restricts the capacity of insurers (Gollier, 2005). Third, from the demand side, the low frequency of earthquake, compared to other natural catastrophes, is easy to incur the wrong perception that earthquake risk is not as high as it actually is, even in the risk-prone area (Swiss Re, 2012b). Owing to shrunken capacity and increased prices, far fewer policyholders purchase catastrophic coverage, unless required by financial covenants in debentures. Thus, a large single earthquake plus a mismatch of supply and demand combine to truly shake the economy. This paper argues that, with some sort of government intervention, catastrophic risk results from an earthquake can be insurable and affordable. If businesses continue to bear substantial amounts of earthquake risk, political realities imply that a governmental bailout would be unavoidable in case of another catastrophic earthquake. In such a circumstance, the governmental intervention would likely by hastily constructed, involve larger amounts of aid, and would not have the same beneficial economic effects as would an existing program implemented by the government.

Japan, New Zealand, and Taiwan have all established government intervention mechanisms. The Japanese government acts as a reinsurer via the Japanese earthquake reinsurance policy. New Zealand's Earthquake Commission, however, is a government-owned crown entity that provides primary natural disaster insurance to the owners of residential properties in New Zealand. Taiwan established the Residential Earthquake Insurance Program, which provides excessive coverage just for homeowners. This paper will compare the similarities and differences of the government-intervened earthquake insurance systems in these three countries and examines whether one is better than another. Moreover, since not all of the above countries have made earthquake insurance completely, this paper will also analyze obstacles facing the successful creation of a compulsory earthquake insurance system while advocating its essentiality.

\section{Issues Associated With Using Insurance as a Mechanism of Managing the Risk of Earthquake Damages}

\section{Insurability}

To establish the insurability of a particular risk, insurance companies generally review the following criteria:

(1) accessibility: The probability and severity of losses must be quantifiable;

(2) randomness: The time at which the insured event occurs must be unpredictable and the occurrence itself must be independent of the will of the insured; 
(3) mutuality: Numerous persons exposed to a given hazard must join together to form a risk community within which the risk is shared and diversified;

(4) economic feasibility: For a risk to be insurable, private insurers must be able to charge a premium commensurate with the risk it covers (the "actuarially justified premium").

For the policyholder to be able to acquire the cover he needs (if insurance is not mandatory), premia must be adequate both for the insurer, who will assess whether it permits the insurance supplied to be profitable under given capital constraints, and for the insured, who should find it affordable and commensurate with his own perception of the risk (Organisation for Economic Co-operation and Development [OECD], 2005).

With regard to the accessibility, for low-probability high-consequence (LPHC) events, analysis of past events reveals wide variations in loss distribution; this hinders insurers' ability to predict the severity and frequency of future events, and thus make them difficult to set actuarial insurance premium commensurate with such risks (OECD, 2005). Nevertheless, various high-quality models aiming to predict the probability of natural catastrophes and losses they incur have been developed in recent years (Risk Management Solutions [RMS], 2008). Since current probabilistic risk assessment models available base on historical hazard activity and no sufficient scientific evidence supporting a deviation from the historic basis is available (Zimmerli, 2004), statistical models based on a combination of historical data and physical modeling actually make the present-day financial risks associated with catastrophe for a specific location or aggregated area better predictable and are useful in managing such risks (Patmore, 2008; RMS, 2008). As modern earthquake catastrophe models adopt the very same methodologies, the earthquake risks are not inaccessible today.

Moral hazard which refers to the effect of insurance on the insured's incentives to reduce expected losses is the problem that can affect the randomness of a particular risk (Harrington \& Niehaus, 1999). The moral hazard problem is particularly crucial when insureds have dominant control over their risk (Gollier, 2005). In that case, purchasers of insurance are presumed to have an informational advantage due to the better understanding of their risks type and the probability of loss, while insurers, facing the asymmetry of information, need to invest significant costs to acquire such information (Bruggeman, 2010). However, in the case of natural disasters, particularly earthquake, given that the probability of catastrophic losses is not private information to the insured, he should have no control over the event incurring the risk so that the moral hazard problem is less likely to be seen in catastrophic insurance market (Harrington, 2000). Although the insured may still have some control over the damage caused by the catastrophe (also known as the ex post moral hazard), it is solvable through the enforcement of risk prevention norms (i.e., Stringent Building Code in earthquake-prone region) and discount premiums for insureds who invest in risk reductions (Gollier, 2005).

Most natural catastrophic risks concentrated in risk-prone regions have a tendency to incur cumulative losses due to the occurrence of a single event (Nell \& Richter, 2005). Hence, natural catastrophe risks can be characterized as highly correlated risks (Nell \& Richter, 2005). Once the insured event occurs, it will give rise to immense claims burdens in a single policy period (Bruggeman, 2010). There is possibility that the loss potential of a single event is so enormous as to exhaust the domestic insurance market's capacity to meet all of its obligations (Nell \& Richter, 2005). Therefore, the prerequisite to pool individual risks is to avoid correlated risks to the extent possible and the insurability of natural catastrophes depends on the ability of the insurer to spread large correlated catastrophe risks over larger risk groups (i.e., reinsurance) or through other instruments in the 
capital market (Bruggeman, 2010). Worldwide catastrophe reinsurance service increases the underwriting capacity when earthquake insurance is not enough, as well as natural disaster perils which may not be anticipated (Earthquake Engineering Research Institute, 2013). Through the diversification of global reinsurance, risks which are locally dependent may be internationally independent (Cummins, 2007). Moreover, in capital markets, catastrophe-linked securities (CAT securities) function as an instrument which provide an additional layer of protection and allow catastrophe risks to be transferred from traditional insurance market to capital market (OECD, 2011). Hence, diversification does not seem to be a factor affecting the insurability of earthquake risks.

There is possibility that the accurate prediction of a devastating earthquake in risk-prone area is high. Therefore, an insurer cannot responsibly offer earthquake coverage without reserving adequate capital for the serious attack; otherwise, it may face the erosion of its reserve for other natural disaster risks, which may ultimately bankrupt it (Grace, Klein, Kleindorfer, \& Murray, 2003). Therefore, a responsible insurer will calculate premiums and reserves based on the high boundary of possible predictions (Global Facility for Disaster Reduction and Recovery [GFDDR], 2011). In that case, whether insurance coverage against earthquake and other natural catastrophe is available depends heavily on the willingness of the purchaser to pay a higher insurance premium (Bruggeman, 2010). The affordability is undoubtedly an issue here. In addition, the price of catastrophe risk insurance in competitive markets is also determined by the demand and supply of such products. The following parts will probe into issues associated with the demand and supply side of catastrophe risk insurance.

\section{Lack of Demand}

Empirical studies indicate that even if catastrophe coverage is offered at actuarially fair premiums in competitive markets, given its low-probability, high-loss nature, demand for coverage remains low (Laury, McInnes, \& Swarthout, 2008). First, "those with a higher perceived vulnerability to future catastrophic losses are more likely to acquire first-party insurance than those who believe that a catastrophe is unlikely to affect their home or their community" (Faure \& Bruggeman, 2008, p. 21). The comprehended probability of loss was a crucial factor in deciding the purchase of catastrophe insurance (Slovic, 1987). "Perceived vulnerability, however, constitutes a problem in the case of low-probability high-consequence events like [earthquake].... Overwhelming evidence from psychologists and behavioral law and economics indicates that those events are systematically misjudged" (Faure \& Bruggeman, 2008, p. 21). Potential victims choose not to purchase coverage because they do not consider the risk of loss to be sufficient for them to acquire insurance protection (Faure \& Bruggeman, 2008). In fact, in lack of recent significant earthquake, many may not even realize the seismic risk in their area (Obersteadt, 2012). "The lack of demand is attributed to ineffective information filtering, particularly with probabilistic information regarding catastrophes" (Faure \& Bruggeman, 2008, p. 26).

Second, the perception of potential victims that the state or the government will provide them with ex post disaster relief regardless of insurance coverage dilutes their incentives in voluntarily purchasing first-party insurance (Van den Bergh \& Faure, 2006). In the absence of insurance, the government may find it difficult to resist the political pressure to provide compensation (Harrington, 2000). Those exposed to the catastrophic risk will retain the insurance premium in their pocket and free-ride on the government if they are certain the ex post state compensation program is in place (Bergh \& Faure, 2006). 
Potential victims of catastrophe risk view insurance as an investment. Psychological studies show that people may prefer uncertain losses rather than the certain loss of paying the premium, and tend to insure against high-probability, low-damage events due to the high probability of pecuniary return (Faure \& Bruggeman, 2008). Very likely, potential victims who purchase first-party insurance against the risk of catastrophic losses but did not experience losses that trigger claims will, within a few years, terminate their insurance contract or not the renew it (Bruggeman, 2010).

Fourth, as insurance premiums should be compatible to the underlying risks with respect to the various risk zones and types of construction, households facing budget constraints may not have interest and/or ability to voluntarily purchase adequate insurance coverage against catastrophic losses (Mahul \& White, 2012). Contrasting to the expected utility model "where the demand for insurance depends on the premium relative to the expected loss, demand under this scenario depends only on the premium for a given amount of coverage" (Bruggeman, 2010, p. 109).

\section{Lack of Supply}

While catastrophe risks are, as indicated, prima facie insurable, there are still problems on the supply side. Except for the lack of demand, some insurers are reluctant to provide coverage for property damage caused by natural catastrophes. Their primary arguments still based heavily on the insurability:

First, natural disasters (hurricane, earthquake, etc.) usually concentrate on specified geographical area and are highly correlative (Kleindorfer \& Kunreuther, 1999). For such correlated risks, the insurer is concerned about the magnitude of claims in a single disaster occur (Kleindorfer \& Kunreuther, 1999). Lessons from past catastrophes revealed that a significant number of insurance companies became insolvent as a result of such catastrophic losses due to the disasters' nature of lack of geographical diversity (Faure \& Bruggeman, 2008). At as a result, it is questionable that how many property insurance policies insurers are willing to offer in risk-prone regions (Kleindorfer \& Kunreuther, 1999).

Second, since insurance risks must be calculated based scientific or historical data, the absence of such data and the present imperfect scientific knowledge leads to "the supply deficiencies of first-party catastrophe coverage" (Bruggeman, 2010, p. 111). The shortage of scientific data for earthquake risks building a model for risk assessment is more like a myth than mathematics (Boardman, 2005). Such uncertainty which impacts the predictability regarding both the probability of a catastrophic event and its losses results in uninsurability of a specific catastrophic event or in a specific risk-prone area (Kunreuther, Hogarth, \& Meszaros, 1993). Although such uncertainty can still be insured be by charging risk premium two to 10 times higher than ordinary property insurance (Kleindorfer \& Kunreuther, 1999), two problems remain: (1) a higher insurance premium directly influences the affordability of catastrophe insurance and hence decreases the demand; and (2) restrictions or caps imposed by insurance regulations which bar insurers from applying high premiums to catastrophic risks also affect insurers' willingness to supply (Faure \& Hartlief, 2003).

Third, as mentioned earlier, concerns the underwriting capacities of insurance companies particularly in the case of catastrophic events. "Reinsurance helps insurance companies underwrite large risks, limits liability on specific risks, increases capacity, and shares liability when claims overwhelm the primary insurer's resources" (Faure \& Bruggeman, 2008, p. 29). Nevertheless, when mega or multiple catastrophic events occur, insurers 
might not have purchased sufficient reinsurance, or reinsurance providers might not have sufficient loss absorbency to meet their existing obligations (Gron, 1999). After a catastrophic loss, the uncertainty regarding the frequency or magnitude of future events might make reinsurers reluctant to reinsure catastrophic event because of the difficulty in pricing catastrophe insurance (Starvish, 2011). In addition, "reinsurance prices may increase after major catastrophes as reinsurance companies attempt to restore their financial condition through higher revenues or coverage restrictions"; otherwise, reinsurance capacity may be diminished and reinsurers might limit availability of future catastrophic reinsurance coverage (United States General Accounting Office, 2003). Since reinsurance provides additional capital to insurers and thus increases underwriting capacity, without reinsurance, insurers could not limit the exposure to severe liability and had no choice but to exclude coverage.

\section{Analysis}

From the preceding analyses, the insurability of the catastrophic earthquake risk directly impacts the insurers' willingness to provide coverage. From the perspective of commercial insurer, although puzzles that affect the insurability can be tackled, others remain unsolvable. Uncertainty in risk assessment has been gradually reduced through the development of modern catastrophe modeling. The moral hazard has never been an issue in the case of natural catastrophe as the insured has no advantageous information over the insurer. Problems remain with the supply side are the capacity of insurer and even the reinsurer, and the affordability of catastrophe insurance. As to the former, even if domestic insurers may diversify catastrophe risks they assume through international reinsurance or other instruments in the capital market, owing to the unpredictability nature of losses of the catastrophic event, there is no guarantee that extremely large losses incurred in a single or multiple events are sufficiently financed by the insurance, reinsurance and catastrophe bonds (Swiss Re, 2012a). When such losses exceed the insurance system's and capital markets' capacity, the only approach to compensate the shortage is to rely on ex post public borrowing or government financing (Swiss Re, 2012a). Otherwise, one single catastrophic event can trigger the crisis in the voluntary insurance market in which insurers are no longer willing to underwrite catastrophe risks (Kousky, 2010). The government intervention can serve as a useful stopgap and ensure the availability of coverage because the government would usually be able to provide much more capacity than private sector (Kousky, 2010; Nell \& Richter, 2005). In regard of the affordability, it is argued that governments can keep the catastrophe insurance stay affordable through legislations (Bruggeman, 2012). When the government plays a role as a reinsurer, it charges an actuarially fair premium for its intervention so that reinsurance is an adequate resolution to the uninsurability problem result from affordability (Bruggeman et al., 2012).

With respect to the lack of demand, since the potential victims of the catastrophe risk are still risk averse to large losses and are willing to pay a premium to have such risks transferred, they do not purchase adequate coverage simply because they are in lack of correct information regarding (Bruggeman, 2010). Through legislation, the government may make the catastrophe insurance or earthquake insurance compulsory in order to cure the asymmetry of information (Bruggeman, 2010). The compulsory insurance scheme also marginalizes the lack-of-incentive problem. Moreover, the government intervention in mandating the potential victims to purchase first-party insurance helps to reduce the costs of government's ex post disaster relief as some of the costs of offsetting the damages have been internalized (Bruggeman, 2010). 
Given that the government intervention in financing catastrophic losses is indispensable for maintaining the capacity of private insurance market and the affordability of the first-party catastrophe risk insurance, it is make sense to advocate the public-private partnership in the provision of catastrophe coverage.

\section{Earthquake Insurance in Asia-Studies on the System in Japan, New Zealand, and Taiwan}

The government can adopt several different approaches in crafting policies to involve in the management of catastrophe risks and compensation to attendant losses:

First, the government can rely primarily on the private insurance market. Second, the government can provide direct compensation to the catastrophe victims. Third, the government can institute mandatory comprehensive insurance. Fourth, the government itself can provide catastrophe insurance. Fifth, the government can share the catastrophe risk with the private sector by acting as a reinsurer of last resort. Sixth, the government can finance catastrophic damages through an additional insurance layer above the insurers' own financing. Finally, new forms of government intervention, such as acting as a lender of last resort, have been proposed (Bruggeman et al., 2012).

Government intervention can also be a mixture of any of the above schemes (Bruggeman et al., 2012). In addition to the ex post compensation, Japan, New Zealand, and Taiwan, the three earthquake risk prone area, happen to apply different measures.

\section{Japan Earthquake Reinsurance (JER)}

On June 16 1964, the Niigata Earthquake (M 7.5) caused 26 dead, 447 injured, and incurred damage to residences, 1,960 were completely destroyed, 6,640 were partially destroyed, 15,297 were flooded, and 67,825 were partially damaged (General Insurance Rating Organization of Japan (GIROJ), 2014).

Facing such situation, the Minister of Finance at that time, convened a general meeting of the Insurance Council and consulted with them concerning concrete measures in order to contribute to the stabilization of the livelihood of the nation shall the earthquake disasters take place (GIROJ, 2014). The Insurance Council considered issues concerning

to cover or not to cover earthquake disaster, insurable property and losses to be covered, prevention of adverse selection, ways for the nation to be involved, the amount to be insured, the limit of total payments, the sharing of liability between the Government and private insurance companies, etc. (GIROJ, 2014)

The Insurance Council eventually delivered a report on an earthquake insurance system in 1965 (GIROJ, 2014).

For implementing an earthquake insurance system, the "Law concerning Earthquake Insurance (LEI)" and its Enforcement Order, and "Earthquake Reinsurance Special Accounting Law (ERISAL)" and its Enforcement Order was promulgated in 1966 (Kuroki, 2003). Issues regarding the detail of the earthquake insurance coverage, standards of payments, caps of underwriting, reinsurance, accounting treatment were specifically addressed in the new legislations (Kuroki, 2003). The latest amendment of the LEI was made on 1999. ${ }^{1}$

Pursuant to Article 3 of the LEI, the Japan Earthquake Reinsurance Co. Ltd. (JER), established with share capital of one billion yen by 20 domestic Japanese non-life insurance companies on May 30, 1966, covers losses

\footnotetext{
$1 \quad$ Law concerning Earthquake Insurance, http://law.e-gov.go.jp/cgi-bin/idxselect.cgi?IDX_OPT $=3 \& H \_N A M E=\& H \_N A M E \_Y O M I=\% 82 \% A 0 \& H \_R Y A K U=1 \& H \_C T G=$

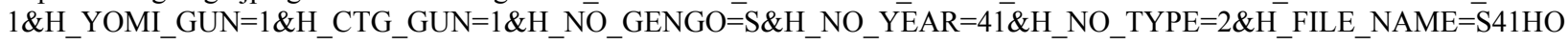
073 (last visited April 5 2013).
} 
to residential buildings and contents result from earthquake, volcanic eruption, or tsunami including fire following such an event. ${ }^{2}$ Premium rates vary in accordance with location, building age and standard (Takashi, 2012). Such design set insurance premiums at the standard affordable for households and businesses. In 2009, approximately 12.3 million policies were outstanding with aggregate insured values of USD1,098 billion, roughly USD90,000 per policy (Takashi, 2012). About $46 \%$ of residential property insurance policies included earthquake insurance coverage (Swiss Re, 2012b).

With regard to the liability sharing mechanism between the first-party insurers, the JER and the government, private insurers and the JER pay first losses per event up to an aggregate USD1.4 billion (Swiss Re, 2012b). The Japanese government pays half of the losses exceeding USD1.4 billion (115 billion Yen) and 95\% of losses exceeding USD10.5 billion (1,925 billion Yen) up to USD66.3 billion (871 billion Yen) (Swiss Re, 2012b). Government liability within the program is limited to USD57.5 billion (Swiss Re, 2012b). Insurers and JER's combined liability is capped at USD8.7 billion. The liability of JER and private insurers was lowered from USD14.4 billion to USD8.7 billion (724 billion Yen) after the devastating earthquake in March 2011 to alleviate private insurers' concern for future earthquake payments (Swiss Re, 2012b). In fiscal year 2009, JER collected USD0.772 billion in net premiums and had assets of USD11.670 billion (Swiss Re, 2012b). The Japanese government remains the insurer of last resort for rare loss events over USD66.3 billion, although the earthquake law stipulates that insurance payouts can be reduced in accordance with the proportion of total claims to the maximum limit, which is 5.5 trillion Yen (Swiss Re, 2012b). Amount of the risk to be carried by the commercial underwriters is determined by the Cabinet Order, while the amount of year. ${ }^{3}$ In case, the total amount of the necessary indemnification exceeds this limit, the amount to be paid to the individual insureds will be reduced proportionately. ${ }^{4}$

\section{New Zealand Earthquake Commission}

In 1933, New Zealand introduced the Earthquake Commission (EQC) which provides natural disaster insurance for residential property, administers the Natural Disaster Fund, and funds research and education on natural disasters and ways of reducing their impact. ${ }^{5}$ Part I of the Earthquake Commission Act (EQC Act) of 1933 provides for the organizational structure, function, and power of the EQC as well as the management of the Natural Disaster fund (New Zealand Legislation, 2008, Art. 4-17).

Part II of the EQC Act The coverage is compulsory whenever fire insurance is purchased (New Zealand Legislation, 2008, Art. 18). The premium for natural disaster coverage is paid to private insurers but then sent to the Earthquake Commission, a state entity, which administers the natural disaster insurance, including processing the claims and organizing reinsurance (New Zealand Legislation, 2008, Art. 23-24). To make EQC affordable, a single rate of premium with maximum limit applies to all homeowners.

For contracts of fire insurance made on or after 1 February 2012, EQCover costs fifteen cents for every $\$ 100$ insured $(0.15 \%)$ where the period of insurance is one year. The maximum for a one-year period is $\$ 150$ for cover of $\$ 100,000$ on the dwelling and $\$ 30$ for cover of $\$ 20,000$ on personal belongings. (EQC, 2012, p. 8)

\footnotetext{
2 Japan Earthquake Reinsurance Co. Ltd., http://www.nihonjishin.co.jp/disclosure/2011/en_05.pdf (last visited April 62013 ).

3 LEI, Art. 3 (1999).

${ }^{4}$ LEI, Art. 4 (1999).

5 EQC, about EQC, http://www.eqc.govt.nz/about-eqc (last visited April 7 2013).
} 
EQC also provides excess coverage based on the number of dwellings in one building. Where the insured property contains only one dwelling, the excess percentage of claim would be $1 \%$ and the minimum and maximum amount payable is NZD\$200 and NZD\$1,150, respectively (EQC, 2012). On the occasion that there are more than one dwelling are included in a single property, the excess payable amount is as follow (EQC, 2012):

(1) For damages to building, NZD \$200 multiplied by the number of dwellings in the building or $1 \%$ of the amount payable, whichever is the greater;

(2) For damages to land, NZD $\$ 500$ multiplied by the number of dwellings in the residential building which is situated on the land, or $10 \%$ of the amount payable, whichever is the greater, to a maximum of $\$ 5,000$;

(3) For damages to both a dwelling and personal property, when a person makes a claim for damage to both a dwelling and personal property located in that dwelling and the damage is caused by the same natural disaster, a single minimum payment of $\$ 200$ applies across both claims.

For the purpose of ensuring the availability of EQCover to most homeowners, the EQC Act also imposed restrictions on the EQC's power to limit the coverage or to cancel the policy. Article 28 of the EQC Act requires a prior notice be given to the insured if the EQC determine to cancel or limit insured's EQCover (New Zealand Legislation, 2008, Art. 28). EQC can only cancel or limit cover in specific circumstances as manifested in Schedule 3 of the Earthquake Commission Act. ${ }^{6}$ EQC bears the duty to advise, in writing, any person affected by the cancellation or limitation of EQCover and explain why it has done so. The notice continues to apply even if a property is sold (New Zealand Legislation, 2008, Art. Schedule $3 \S 4$ ).

Last but not least, EQCover is government guaranteed (EQC, 2013). In case that EQC receive a very large number of claims after a mega catastrophic earthquake that exceeds its capacity to meet all the obligations from the Natural Disaster Fund and its reinsurance, the government will pay the shortfall (EQC, 2013).

\section{Taiwan Residential Earthquake Insurance Fund (TREIF)}

After the Jiji Earthquake on 21 September 1999, the legislature passed amendments to Article 138-1 of the Insurance Law to include provisions on underwriting residential earthquake insurance by the insurers and establishment of a government-funded mechanism for assuming excessive losses caused by earthquake risk. ${ }^{7}$ The Taiwan Residential Earthquake Insurance Fund (TREIF) was therefore created as a public non-profit

\footnotetext{
${ }^{6}$ According to Section 4 of the Schedule of the EQC Act, the coverage can only be cancelled where: "(a) The Commission settles a claim in respect of any property by payment of the full amount to which that property is insured under this Act; and (b) the property in respect of which the claim is settled is neither replaced nor reinstated to the satisfaction of the Commission".

7 Insurance Act (Taiwan), Art. 138 (2012): "(1) Non-life insurance enterprises shall underwrite residential earthquake risk, and shall do so by means of the risk spreading mechanism established by the competent authority. (2) The Taiwan Residential Earthquake Insurance Fund shall be established to manage the risk spreading mechanism referred to in the preceding paragraph. The portion of risk that exceeds the co-insurance underwriting assumption limit for non-life insurance enterprises shall be assumed by the Taiwan Residential Earthquake Insurance Fund, cede to domestic and/or foreign reinsurers, be assumed by the manner prescribed by the competent authority or assumed by the government. (3) With respect to the risk spreading mechanism under the preceding two paragraphs, the competent authority shall prescribe regulations governing the risk assumption limits, insured amounts, insurance premium rates, provision for various reserve funds, and other compliance matters. (4) The competent authority shall prescribe regulations governing the Taiwan Residential Earthquake Insurance Fund's articles of incorporation, business scope, funds allocations, and other administrative matters. (5) When the occurrence of a major earthquake results in payable claims that exceed the amount of funds accumulated in the Taiwan Residential Earthquake Insurance Fund, in order to safeguard the interests of insured the Fund may as necessary request the competent authority and the Ministry of Finance to jointly apply for Executive Yuan's approval of collateral provided by the national treasury to obtain the necessary source of funding".
} 
organization on 9 July 2001, and began operation on 1 April 2002 (TRIEF, 2013a). While the TREIF insures residential buildings against fire, explosion, landslide, land subsidence, land movement, land rupture, tidal wave, surge and flood caused by earthquake, policies are offered by insurance companies (TRIEF, 2013a). At the end of 2012, TREIF had approximately 2.4 million policies in force covering $30.11 \%$ of all households with USD98.3 billion (NTD\$4.04 trillion) sum insured (average USD42,800 per policy) (TRIEF, 2013b).

On December 1, 2005, The Financial Service Commission enacted amendments to the "Enforcement Rules for Coinsurance and Risk Assumption Mechanism of Residential Earthquake Insurance", under which the risk-sharing system was adjusted from four tiers to two tiers. On December 1, 2005, the competent authority promulgated the amended "Enforcement Rules for Coinsurance and Risk Assumption Mechanism of Residential Earthquake Insurance (Risk Spreading Rule)" under which the risk-bearing system was adjusted from four tiers to two tiers (TRIEF, 2013a). The latest amendment of which was introduced on January 12013 (Ministry of Justice, 2013, Art. 10). Pursuant to the Risk Spreading Rule, Insurance the TREIF The program's liability structure is as follows (Ministry of Justice, 2013):

(1) Local property \& casualty insurance companies take up the first NTD $\$ 3$ billion (USD100 million) in losses (Art. 3[1]).

(2) TREIF is liable for the next NTD\$67 billion (USD2.25 billion) (Art. 3[2]).

(3) Losses to be assumed by the TRIEF are diversified to the private reinsurance and capital markets up to NTD $\$ 53$ billion (USD1.75 billion) (Art. 5[1]).

(4) The final portion assumed by TREIF between NTD $\$ 53$ billion to $\$ 67$ billion is retained by the Taiwanese government (Art. 5[2]). Should losses incurred by a single catastrophe exceeds the capacity of the TREIF, the government guarantee is ultimately provided (Art. 5[3]).

In addition, the premium of the earthquake insurance has been set at very affordable level by charging flat premium (TRIEF, 2013a). From April 1, 2009, the annual flat premium for the insurance was reduced from NTD $\$ 1,459$ to NTD $\$ 1,350$ (approximately USD45), with a maximum sum insured of NTD $\$ 1.2$ million (USD40,000) per policyholder (TRIEF, 2013a). While effective from January 1, 2012, the maximum sum insured per policyholder was increased to NTD $\$ 1.5$ million (USD50,000) and the maximum contingent living expense was also increased to NTD\$200,000 (USD6,667) (TRIEF, 2013a).

\section{Comparison and Analysis}

Comparison. In comparison, although Japan, New Zealand, and Taiwan all have in place an earthquake insurance mechanism established in accordance with the public-private-partnership model, the three systems have similarities and differences from one another. Table 1 provides an overall comparison amongst the JRE, the EQC, and the TREIF.

Analysis. With regard to the relatively low and flat rate adopted in New Zealand and Taiwan, critiques argue that while the artificially low and flat premiums charged on the one hand ensures the affordability of earthquake insurance, it, one the other hand, increases ex post moral hazard by removing important incentives for prevention measures and directing building activity toward less risky areas (Klein, 2008). Lax prevention measures and buildings concentrated in risk-prone areas ultimately leads to higher losses and the external costs thus incurred have to be subsidized by taxpayers in lower risk areas (Kousky, 2010). This paper, however, 
argue that since affordability is the most crucial factor that influence both the demand and supply of the earthquake insurance, and the availability of earthquake insurance directly contributes to the post disaster recovery economic stability, the policy of introducing low and flat rate should be maintained even though it is not flawless. Under this premise, this paper further asserts that other prevention measures can still be enforced through other policy instruments, for example, the local building codes. ${ }^{8}$

Table 1

Overall Comparison Amongst the JRE, the EQC, and the TREIF

\begin{tabular}{|c|c|c|c|}
\hline $\begin{array}{ll}\text { Programs } \\
\text { to compare }\end{array}$ & JER & EQC & TREIF \\
\hline Risks covered & $\begin{array}{l}\text { Losses arising concerning the object } \\
\text { Insured due to fire, destruction, } \\
\text { burial or flood directly or indirectly } \\
\text { caused by earthquake, volcanic } \\
\text { eruption or tsunami. }\end{array}$ & $\begin{array}{l}\text { Losses cause from } \\
\text { earthquake or natural } \\
\text { disaster (i.e., flood). }\end{array}$ & Losses incurred by earthquake \\
\hline $\begin{array}{l}\text { Area where coverage is } \\
\text { provided }\end{array}$ & Domestic & Domestic & Domestic \\
\hline $\begin{array}{l}\text { Entity bearing the liability } \\
\text { of indemnity. }\end{array}$ & $\begin{array}{l}\text { - Private insurers } \\
\text { - JER (formed by private insurers) } \\
\text { - Government }\end{array}$ & $\begin{array}{l}\text { EQC (jointly capitalized } \\
\text { by the government and } \\
\text { private insurers) }\end{array}$ & $\begin{array}{l}\text { - } \text { Private P \& C insurers } \\
\text { TREIF (funded by the } \\
\text { government) } \\
\text { - Government }\end{array}$ \\
\hline Duties of private insurers & $\begin{array}{l}\text { - Sale of earthquake insurance } \\
\text { - } \text { Claim adjustment } \\
\text { - Payment of proceeds } \\
\text { - Partial loss sharing }\end{array}$ & $\begin{array}{l}\text { Sale of earthquake } \\
\text { insurance only }\end{array}$ & $\begin{array}{l}\text { - Sale of earthquake insurance } \\
\text { - Claim adjustment } \\
\text { - Payment of proceeds } \\
\text { - Partial loss sharing }\end{array}$ \\
\hline Role of the government & Partial loss sharing \& Reinsurance & $\begin{array}{l}\text { Unlimited guarantee to the } \\
\text { EQC }\end{array}$ & $\begin{array}{l}\text { Partial loss sharing, reinsurance and } \\
\text { unlimited guarantee to the TREIF }\end{array}$ \\
\hline Burden of the treasury & None & Yes & Yes \\
\hline $\begin{array}{l}\text { Caps of compensation in a } \\
\text { single event }\end{array}$ & 5.5 trillion Yen (USD55 billion) & Unlimited & NTD70 billion (USD2.3 billion) \\
\hline Compulsory or voluntary & Voluntary & $\begin{array}{l}\text { - Building: Compulsory } \\
\text { when voluntarily } \\
\text { purchasing fire policy } \\
\text { - Personal belongings: } \\
\text { voluntary }\end{array}$ & Voluntary \\
\hline Rate of premium & $\begin{array}{l}\text { Premium rates vary in accordance } \\
\text { with location, building age and } \\
\text { standard. }\end{array}$ & Flat $(0.05 \%)$ & Flat $(0.12 \%)$ \\
\hline
\end{tabular}

Note. Source: Independent researches conducted by the author.

\section{Remaining Issue: Should Earthquake Insurance Be Compulsory?}

As stated earlier, homeowners' lack of information and expectation constitutes disincentives of demand for earthquake coverage, and making the earthquake insurance compulsory is one possible solution for facilitating the supply of information and raising the penetration rate of the earthquake insurance. Empirical evidence has shown that New Zealand which mandates the earthquake coverage to be attached to homeowners' Fire Insurance Policy at the time of purchase has the highest penetration rate around 90 percent (EQC, 2011), while Japan and Taiwan in which earthquake coverage can be acquired on a voluntarily basis merely has 46 percent and 31

${ }^{8}$ For example, The "Construction Act" and the "Rules of Construction Techniques" all provides for the anti-seismic standard. 
percent respectively. Despite the positive relevancy between compulsory earthquake coverage and the penetration rate, there are pros and cons for the compulsory catastrophe insurance.

\section{Arguments for Compulsory Earthquake Insurance}

Advocates for compulsory catastrophe insurance present three major arguments:

First, the class economic rationale indicates that "an insurance organized through government may be cheaper than a coverage organized through the private insurance market since it may be more effective to insure certain risks on a collective basis" (Faure, 2005, p. 8).

Second, another traditional economic argument in favor of compulsory insurance would be the presence of information problems because compulsory insurance may cure potential victims' scarcity of motivation to purchase coverage due to the problem of asymmetric information (Faure \& Bruggeman, 2008). The basic assumption is that potential victims, being a rational risk-averse person, would purchase insurance coverage, has he been well informed about the risks and the benefits of insurance, but information deficiencies lead them to underestimate the risk and come up with wrongful decision as fail to buy first-party insurance (Faure, 2005). Regulation imposing a general duty to insure extinguishes the information problem (Schwartz \& Wilde, 1979).

Third, as indicated earlier, potential victims are underinsured or not insured because they are overconfident that the risk would not happen to them (Sandroni \& Squintani, 2007). Under such circumstances, "compulsory insurance does not harm unbiased agents because they want to be insured, and should be imposed on overconfident individuals for their own benefit" (Sandroni \& Squintani, 2007, p. 1994).

\section{Arguments Against Compulsory Earthquake Insurance}

Objections to compulsory first-party catastrophe insurance can be broken down into four points.

First, compulsory insurance ignores the fact that the demand for insurance may vary according to the individual risk situation (and financial possibility) of every possible victim under the premise that all individuals are equally well informed about the risks (Bruggeman, 2010).

The introduction of a generalized duty to insure might be inefficient in as far as it forces some people that would normally not have a demand for insurance to purchase insurance. Insurance does not increase these people's expected utility. A generalized duty to insure might therefore create a social loss (Bruggeman, 2010).

Second, if the low penetration rate of catastrophe insurance causes from potential victims' information deficiencies regarding their potential exposure to disasters and on the benefits of first-party insurance, a regulatory solution should be promoting a mandatory disclosure of such information to potential victims instead of creating a general obligation to purchase coverage (Faure \& Grimeaud, 2000).

Third, compulsory insurance scheme mandates all individuals to take insurance coverage, even those that run no risk at all and therefore have no demand for insurance (Bruggeman, 2010). This is deemed inefficient as it lead to cross-subsidization or negative redistribution whereby those who bear no risk would still need to contribute to the premium of those who may actually benefit from the insurance coverage (Harrington, 2000).

Fourth, in terms of disadvantages of anti-competition drawbacks, the New Zealand model cannot avoid the anti-competitive effect of tying (Bergh \& Faure, 2006). In addition, in the case of compulsory insurance, the charge of premium for catastrophe coverage based on flat rate instead of risk based restricts the price competition (Bergh \& Faure, 2006). Furthermore, as in a free market, insurers should be left free to choose whether or not to 
join co-reinsurance groups, mandatory reinsurance also will raise the concern of anti-competition (Bergh \& Faure, 2006).

\section{Comments}

Reviewing arguments both for and against compulsory insurance, this paper asserts that the merits or compulsory insurance outweigh its demerits. The first points disfavoring compulsory insurance does not exist in the real world because even professional insureds consider the catastrophe risk difficult to predict due to its low-frequency high-loss nature, not to mention potential victims, mostly lay person, who are still in lack of capability in accurately assessing such risk despite that they are provided with certain information. The second objecting argument does not make sense as mandatory disclosure of information and mandatory insurance does not contradicts with each other. Rather, their co-existence may produce better well-beings. With respect to the cross-subsidization arguments, there are not unsolvable. A more efficient and fairer solution may be achieved through the introduction of compulsory coverage in risk-prone area only, or by charging additional risk premium in accordance with the individual risk situation of each insured (Faure \& Bruggeman, 2008). Last, as enhancing competition has never been the policy goal of the compulsory insurance, it is the least concern when the establishing the compulsory insurance scheme.

\section{Concluding Remarks}

To summarize, insurance is proven to play a crucial role in post-disaster financing and contributes to the acceleration of the recovery process. Although risk of losses incurred from catastrophic event, like earthquake, are generally insurable, the low-frequency high-loss nature of such risk may lead to the insufficient underwriting capacity of private insurers and hence impact the supply side of catastrophe insurance. This paper advocates that the public-private partnership model will effectively enlarge the capacity of private insurers and simultaneously make the catastrophe insurance more affordable. Countries facing earthquake damage risks in Asia, namely, Japan, New Zealand, and Taiwan, have all adopted this model. Moreover, since the low penetration rate of earthquake insurance caused from homeowners' ignorance about the risk to which they are exposed and unwillingness to "invest" in insurance covering unlikely events, introduction of the compulsory insurance scheme will cure all of these problems.

\section{References}

Boardman, M. E. (2005). Known unknowns: The illusion of terrorism insurance. Georgetown Law Journal, 93(3), 783-844.

Bruggeman, V. (2010). Compensating catastrophe victims - A comparative and economic approach. Zuid-Holland, Netherlands: Wolters Kluwer

Bruggeman, V., Faure, M., \& Heldt, T. (2012). Insurance against catastrophe: Government stimulation of insurance markets for catastrophic events. Duke Environmental Law \& Policy Forum, 23, 185-220.

Cummins, J. D. (2007). Reinsurance for natural and man-made catastrophes in the United States: Current state of the market and regulatory reforms. Risk Management and Insurance Review, 10(2), 179-220.

Dong, W. M., Morrow, G., Tanaka, A., Kagawa, H., Chou, L. C., Tsai, Y. B, ... Chiangm, W. L. (2000). Event report, Chi-Chi Taiwan earthquake. Retrieved from https://forms2.rms.com/rs/729-DJX-565/images/eq_chi_chi_taiwan_eq.pdf

Earthquake Engineering Research Institute. (2013). Earthquake reinsurance. Retrieved from https://www.eeri.org/earthquake-reinsurance/

Earthquake Commission (EQC). (2011). EQC briefing to the incoming minister. Retrieved from http://www.eqc.govt.nz/sites/public_files/min-briefing-11.pdf 
EQC. (2012). EQCover: The insurer's guide. Retrieved from http://www.eqc.govt.nz/what-we-do/eqc-insurance/insurers-guide EQC. (2013). EQC Insurance. Retrieved from http://www.eqc.govt.nz/what-we-do/eqc-insurance

Faure, M. (2005). Economic criteria for compulsory insurance. Retrieved from http://arno.unimaas.n1/show.cgi?fid=7051

Faure, M., \& Bruggeman, V. (2008). Catastrophic risks and first-party insurance. Connecticut Insurance Law Journal, 15(1), 21-27.

Faure, M., \& Grimeaud, D. (2000). Financial assurance issues of environmental liability. Retrieved from https://ec.europa.eu/environment/legal/liability/pdf/insurance_gen_finalrep.pdf

Faure, M., \& Hartlief, T. (2003). Insurance and expanding systematic risks. Paris: Organization for Economic Co-operation and Development.

General Insurance Rating Organization of Japan (GIROJ). (2014). Earthquake insurance in Japan. Retrieved from https://www.giroj.or.jp/english/pdf/Earthquake.pdf

Global Facility for Disaster Reduction and Recovery (GFDDR). (2011). Catastrophe risk insurance pricing. Retrieved from http://www.gfdrr.org/sites/gfdrr.org/files/documents/DRFI_CatRiskPricing_Concept_Apr11.pdf

Gollier, C. (2005). Some aspects of the economics of catastrophe risk insurance. In OECD (Ed.), Catastrophic risk and insurance: Hurricane and hydro meteorological risks (p. 18). Retrieved from http://www.oecd.org/finance/insurance/36816550.pdf

Grace, M. F., Klein, R. W., Kleindorfer, P. R., \& Murray, M. R. (2003). Catastrophe insurance: Consumer demand, markets and regulation. New York: Springer.

Gron, A. (1999). Insurer demand for catastrophe reinsurance. In K. A. Froot (Ed.), The financing of catastrophe risk. Chicago: University of Chicago Press.

Harrington, S. E. (2000). Rethinking disaster policy. Regulation, 23(1), 40-42.

Harrington, S. E., \& Niehaus, G. R. (1999). Risk management and insurance. New York City, United States: McGraw-Hill Companies, Incorporated.

Klein, R. (2008). Catastrophe risk and the regulation of property insurance. Retrieved from http://rmictr.gsu.edu/Papers/WP08-1.pdf

Kleindorfer, P., \& Kunreuther, H. (1999). Challenges facing the insurance industry in managing catastrophic risks. In K. A. Froot (Ed.), The financing of catastrophe risk. Chicago: University of Chicago Press.

Kousky, C. (2010). Managing the risk of natural catastrophes: The role and functioning of state insurance programs. Retrieved from https://citeseerx.ist.psu.edu/viewdoc/download?doi=10.1.1.569.6894\&rep=rep1\&type=pdf

Kunreuther, H., Hogarth, R., \& Meszaros, J. (1993). Insurer ambiguity and market failure. Journal of Risk and Uncertainty, 7(1), 71-87.

Kuroki, M. (2003). Jishin hoken no holi to kadai (Issues and jurisprudence of earthquake insurance). Tokyo, Japan: Seibundoh Publishing Co.

Laframboise, N., \& Loko, B. (2012). Natural disasters: Mitigating impact, managing risks. IMF Working Paper 12/245. Retrieved from http://www.imf.org/external/pubs/ft/wp/2012/wp12245.pdf

Laury, S., McInnes, M. M., \& Swarthout, J. T. (2008). Insurance purchase for low-probability losses. Andrew Young School of Policy studies research paper No. 08-05. Retrieved from https://ssrn.com/abstract=1090266

Mahul, O., \& White, E. (2012). The economics of disaster risk, risk management and risk financing-Earthquake risk insurance. Retrieved from http://wbi.worldbank.org/wbi/Data/wbi/wbicms/files/drupal-acquia/wbi/drm_kn6-2.pdf

Ministry of Justice. (2013). Enforcement rules for coinsurance and risk assumption mechanism of residential earthquake insurance. Retrieved from https://law.moj.gov.tw/Eng/LawClass/LawAll.aspx?pcode=G0390041

Nell, M., \& Richter, A. (2005). Catastrophic events as threats to society: Private and public risk management strategies. In Frenkel, M., Hommel, U., and Rudolf, M. (Eds.), Risk management: Challenge and opportunity (2nd ed., pp. 321-340). Berlin: Heidelberg.

New Zealand Legislation. (2008). Earthquake Commission (EQC) Act 1993. Retrieved from http://www.legislation.govt.nz/act/public/1993/0084/7.0/096be8ed80659c86.pdf

Obersteadt, A. (2012). Insurance regulator strategies to reduce earthquake insurance barriers. Retrieved from http://www.naic.org/documents/cipr_earthquake_insurance_research_report.pdf

Organization for Economic Cooperation and Development (OECD). (2005). Terrorism risk insurance in OECD countries. Retrieved from http://faculty.haas.berkeley.edu/jaffee/papers/091DJOECD.pdf

OECD. (2011). Risk awareness, capital markets and catastrophic risks. Retrieved from https://www.oecd.org/daf/fin/insurance/riskawarenesscapitalmarketsandcatastrophicrisks-policyissuesininsurance.htm

Patmore, N. (2008). Using insurance catastrophe models to investigate the economics of climate change impacts and adaptation. Retrieved from http://personal.lse.ac.uk/RANGERN/Patmore_IDRC08_catmodelling.pdf 
Risk Management Solutions (RMS). (2008). The review: A guide to catastrophe modelling. Retrieved from https://forms2.rms.com/rs/729-DJX-565/images/rms_guide_catastrophe_modeling_2008.pdf

Sandroni, A., \& Squintani, F. (2007). Overconfidence, insurance, and paternalism. American Economic Review, 97(5), $1994-2004$.

Schwartz, A., \& Wilde, L. L. (1979). Intervening in markets on the basis of imperfect information: A legal and economic analysis. Pennsylvania Law Review, 127, 630-634.

Slovic, P. (1987). Perception of risk. Science, 236(4799), 280-285. Retrieved from http://socsci2.ucsd.edu/ aronatas/project/academic/risk\%20slovic.pdf

Starvish, M. (2011). Doomsday coming for catastrophic risk insurers? Retrieved April 3, 2013, from http://hbswk.hbs.edu/item/6774.html

Swiss Re. (2012a). Lessons from recent major earthquakes. Retrieved from https://www.swissre.com/institute/library/Expertise-Publication-lessons-from-recent-major-earthquakes.html

Swiss Re. (2012b). New Swiss Re report reveals low earthquake insurance penetration globally, even in countries with high $\begin{array}{llllll}\text { seismic } & \text { risk. } & \text { Retrieved } & \text { March } & 31, & \text { 2013, }\end{array}$ https://reliefweb.int/sites/reliefweb.int/files/resources/News_release_exp_pub_Lessons_from_earthquakes_Jan_2012.pdf

Taiwan Residential Earthquake Insurance Fund (TRIEF). (2013a). Introduction to the TRIEF. Retrieved from http://www.treif.org.tw/e_contents/A_aboutTREIF/A1.aspx

TRIEF. (2013b). Business overview: Finance. Retrieved from http://www.treif.org.tw/e_contents/B_financial/B1.aspx

Takashi, Y. (2012). Jishin hoken seido (The earthquake insurance system). Tokyo, Japan: Kinzai Institute of Financial Affairs.

United States General Accounting Office. (2003). Catastrophe insurance risks: Status of efforts to securitize natural catastrophe and terrorism risk. Retrieved from http://www.gao.gov/assets/240/239883.pdf

Van den Bergh, R., \& Faure, M. (2006). Compulsory insurance of loss to property caused by natural disasters: Competition or solidarity. World Competition, 29(1), 25-54.

Zimmerli, P. (2004). Insurance of atmospheric perils-Challenges ahead. OECD Conference on Catastrophic Risks and Insurance, November 22-23, Paris, France. 